\title{
Model optimalisasi peran Ketua Rukun Tetangga dalam mencegah perceraian
}

\author{
Model of optimizing the role of chairmen of neighborhood in preventing \\ divorce
}

\author{
Dyah Retna Puspita, Pawrtha Dharma, \& Rukna Idanati
}

\author{
Jurusan Administrasi Negara, FISIP Universitas Jenderal Soedirman, Purwokerto \\ Jalan Prof. Dr. H. Bunyamin 993, Purwokerto 53122, Indonesia \\ E-mail: dyahrpuspita@yahoo.com
}

\begin{abstract}
The rising number of divorce in Purbalingga encourages the idea to optimize the divorce prevention effort by conducting family resilience counsulting. The target is neighbourhood association whose members are mostly men. Approach to them are necessary because they were rarely became the target of family counseling. As a social organization, activities within neighbourhood association are highly depends on its chairman. This research analyzes (1) neighbourhood association chairman's view regarding the divorces phenomena in Purbalingga Regency and (2) their roles in prevent divorces in their area. This research was conducted in District of Purbalingga which has high number of divorce cases. Sample locations for this research consist of four urban areas which purposively selected using chairman as responden. Data obtained through questionnaires and discussion groups, analyzed by simple quantitative techniques. The study shows that, firstly, most of respondents are lacking of awareness of the divorces phenomena in Purbalingga regency. This is because the association never receives the information or report of divorces. Second, there are several respondents that reported their cases to chairmen, but most of chairmen did not have the power to prevent it, because people who asked for divorce administration letter had their final decision to separate with their partner. Results lead to conclusion that the effort to decrease the number of divorce can be held by giving continual consultation to men about family resilience.
\end{abstract}

Keywords: neighbourhood association forum, family resilience consultation, divorce, Purbalingga

\begin{abstract}
Abstrak
Maraknya perceraian di Purbalingga mendorong gagasan untuk meningkatkan upaya pencegahannya melalui penyuluhan ketahanan keluarga. Sasarannya adalah organisasi Rukun Tetangga (RT) yang kebanyakan pesertanya adalah kaum laki-laki. Pendekatan terhadap mereka perlu dilakukan disebabkan selama ini mereka nyaris tidak pernah menjadi sasaran penyuluhan tentang keluarga. Sebagai organisasi kemasyarakatan yang bersifat sosial, maka kegiatannya sangat tergantung kepada Ketuanya. Untuk itulah penelitian ini bertujuan mengkaji: (1) pandangan para Ketua RT tentang fenomena perceraian di Kabupaten Purbalingga dan (2) peran mereka dalam mencegah kasus perceraian di wilayah mereka. Lokasi penelitian adalah Kecamatan Purbalingga yang angka kasus perceraiannya termasuk tinggi. Sampel lokasi adalah empat kelurahan/desa yang dipilih secara purposive dengan pertimbangan utama keaktifan organisasi RT. Semua Ketua RT di empat wilayah ini dipilih menjadi sampel. Dengan kata lain, ini adalah penelitian sensus. Data diperoleh melalui kuesioner dan diskusi kelompok yang dianalisis dengan teknik kuantitatif sederhana. Hasil penelitian menunjukkan bahwa: pertama, kebanyakan responden kurang mengetahui fenomena perceraian di Kabupaten Purbalingga, karena forum RT tidak pernah mendapatkan informasi tersebut. Kedua, selama menjadi Ketua RT, ada beberapa responden yang di wilayahnya terjadi kasus perceraian, tetapi kebanyakan tidak mampu mencegahnya, karena warga yang datang untuk meminta surat pengantar mengurus perceraian tersebut kebanyakan sudah bulat keputusannya. Dari hasil ini disimpulkan bahwa upaya menurunkan kasus perceraian dapat dilakukan dengan melakukan penyuluhan ketahanan keluarga kepada kaum laki-laki secara berkesinambungan.
\end{abstract}

Kata kunci: Forum Rukun Tetangga, penyuluhan ketahanan keluarga, perceraian, Purbalingga

\section{Pendahuluan}

Pasal 1 Undang-undang Nomor 52 Tahun 2009 tentang Perkembangan Kependudukan dan Pembangunan Keluarga menyebutkan bahwa pembangunan keluarga adalah upaya mewujudkan 
keluarga berkualitas yang hidup dalam lingkungan yang sehat. Salah satu ciri keluarga berkualitas adalah dibentuk dari perkawinan yang sah. Menurut pasal 1 Undang-undang Nomor 1 Tahun 1974 tentang Perkawinan, perkawinan ialah ikatan lahir batin antara seorang pria dengan seorang wanita sebagai suami istri dengan tujuan membentuk keluarga (rumah tangga) yang bahagia dan kekal berdasarkan Ketuhanan Yang Maha Esa. Selanjutnya, di dalam pasal 38 disebutkan bahwa suatu perkawinan dapat putus karena tiga hal yakni: (1) kematian, (2) perceraian, dan (3) atas keputusan Pengadilan.

Fenomena perceraian saat ini terjadi di hampir semua wilayah di Indonesia. Direktorat Jenderal Badan Peradilan Agama (Badilag) Mahkamah Agung RI mencatat dalam lima tahun terakhir kasusnya meningkat tajam, dari 57.114 kasus (tahun 2010) menjadi 98.154 kasus (tahun 2011). Peningkatan lebih tajam terjadi tahun 2012 dengan 403.001 kasus. Setiap tahun, jumlah terbanyak adalah cerai gugat yang berarti pengajunya adalah pihak istri. Pada tahun 2010 dan 2011 penyebab terbanyak adalah karena salah satu pihak meninggalkan kewajiban, terutama dalam bentuk tidak bertanggung jawab dan faktor ekonomi (52,07 persen di tahun 2010 dan 50,75 persen di tahun 2011). Adapun penyebab ketiga adalah karena terus-menerus berselisih (39,40 persen di tahun 2010 dan 40,44 persen di tahun 2011) (Direktorat Jenderal Badan Peradilan Agama Mahkamah Agung RI dalam badilag.net).

Kondisi yang serupa terjadi di Jawa Tengah di mana peningkatan tajam juga terjadi tahun 2012 yakni sebanyak 90.607 kasus dari yang semula hanya 9.770 kasus (tahun 2010) dan 17.464 kasus (tahun 2011). Sekitar 60 persennya adalah juga merupakan cerai gugat (Pengadilan Tinggi Agama Semarang dalam http://www.pta-semarang.go.id/kepaniteraan/arsip/Faktorceraipbr2011.pdf).

Salah satu kabupaten di Jawa Tengah yang kasus perceraiannya tinggi dan meningkat adalah Purbalingga. Di kabupaten ini persentase cerai gugatnya bahkan mencapai sekitar 70 persen. Jika tahun 2012 terdapat 2.920 kasus, maka tahun 2014 sedikit menurun menjadi 2.832 kasus. Empat penyebab terbanyaknya adalah karena tidak adanya tanggung jawab dan faktor ekonomi $(71,93$ persen), ketidakharmonisan (11,89 persen) dan kekejaman jasmani ( 1,32 persen) dan kekejaman mental (0,06 persen) (Pengadilan Agama Kabupaten Purbalingga dalam http://pa-purbalingga.go.id/ index.php?option=com_content $\&$ view=article $\&$ id=404\&Itemid=192\&lang=id).

Dari faktor-faktor penyebab perceraian di tingkat nasional maupun di Purbalingga di atas tampak adanya keterkaitan antara perceraian dengan Kekerasan Dalam Rumah Tangga (KDRT). Di dalam Undang-undang Nomor 23 tahun 2004 tentang Penghapusan Kekerasan dalam Rumah Tangga (PKDRT) pasal 11 disebutkan bahwa Pemerintah bertanggung awab dalam upaya pencegahan KDRT. Selanjutnya pada pasal 14 disebutkan bahwa dalam rangka upaya ini, Pemerintah dapat bekerja sama dengan masyarakat atau lembaga sosial lainnya. Dengan demikian, partisipasi masyarakat sangat diperlukan, baik secara individu, kelompok maupun organisasi.

Dalam kenyataannya, sosialisasi tentang KDRT dan UU PKDRT lebih banyak ditujukan kepada kaum perempuan. Kajian Puspita dkk. (2014) di Kabupaten Purbalingga menemukan bahwa kaum laki-laki nyaris tidak pernah mendapatkan informasi tentang KDRT maupun issu keluarga lainnya seperti kesehatan reproduksi dan KB. Kebanyakan alasan yang diajukan para kader PKK maupun Penyuluh KB adalah karena forum pertemuan warga laki-laki (yang kebanyakan berupa forum pertemuan Rukun Tetangga/RT) hampir selalu diadakan pada malam hari dan di luar hari kerja (biasanya Sabtu atau Minggu malam). Hal ini membuat sebagian besar kader (yang semuanya adalah perempuan dan sebenarnya adalah juga warga setempat) merasa sungkan untuk masuk ke dalam forum tersebut. Kendala lainnya adalah karena mereka merasa kurang percaya diri untuk berbicara dalam forum tersebut. Sementara itu, Penyuluh KB yang merupakan penyuluh resmi (Pegawai Negeri) yang bertugas memberikan informasi dan motivasi kepada warga seputar KB dan issu-issu keluarga lainnya, juga sangat jarang memanfaatkan forum ini. Di samping karena alasan di luar jam dan hari kerja, juga karena sebagian besar dari mereka tidak tinggial di wilayah tersebut. Bahkan tidak sedikit yang tinggal di luar kota. Penyebab lainnya adalah karena banyak penyuluh yang hampir memasuki usia pensiun, sehingga semangat kerja mulai menurun. 
Padahal, kebanyakan pelaku KDRT adalah laki-laki. Dengan demikian, pengabaian pemberian informasi terhadap kelompok ini justru akan membuat mereka semakin rentan melakukan berbagai tindak kekerasan disebabkan ketidaktahuan mereka. Sangat terbatasnya sosialisasi kepada mereka inilah yang diduga menyebabkan terhambatnya upaya pencegahannya. Kasus-kasus KDRT terus saja bermunculan, baik yang dilaporkan maupun yang tidak dilaporkan. Untuk itulah maka pelibatan kaum laki-laki dalam upaya pencegahan dan penghapusan KDRT menjadi hal yang mendesak untuk dilakukan. Hal ini sejalan dengan pendapat Flood (2010) yang mengatakan bahwa sebetulnya kebanyakan laki-laki juga menganggap KDRT sebagai sesuatu yang tidak dapat diterima dan seiring dengan peningkatan kasus-kasus KDRT, terjadi pula perbaikan perilaku di kalangan laki-laki.

Sebetulnya forum RT (yang kebanyakan diikuti warga laki-laki dan di banyak tempat masih berjalan) dapat dioptimalkan untuk menyosialisasikan hal tersebut. Caranya adalah dengan mengoptimalkan peran Ketua RT sebagai "tenaga penyuluh"nya. Hal ini sesuai dengan salah satu tugas mereka yakni dalam pemeliharaankeamanan, ketertiban dan kerukunan hidup antar-warga menurut pasal 4 Peraturan Menteri Dalam Negeri Nomor 5 Tahun 2007 tentang Pedoman Penataan Lembaga Kemasyarakatan yakni. Agar dapat menjalankan peran ini, maka perlu dikaji terlebih dahulu sejauh mana pemahaman mereka tentang fenomena perceraian dan KDRT terutama di Kabupaten Purbalingga serta sejauh manaperan mereka dalam upaya pencegahannya di lingkungan mereka.

Perlunya pelibatan laki-laki dalam issu-issu keluarga juga dapat dilihat dari beberapa hasil penelitian. Di bidang KB misalnya, penelitian Imroni dkk. (2009) yang mengaji para ibu yang menggunakan metode implan di desa Parit, Kecamatan Indralaya Utara Kabupaten Ogan menemukan bahwa faktor yang terbukti memengaruhi tingkat penggunaan implan ibu-ibu tersebut adalah sikap mereka pada metode implan serta dukungan suami.

Hasil penelitian senada juga ditemukan di Malawi. Diketahui bahwa rendahnya tingkat partisipasi KB dan tingginya kehamilan beresiko ternyata disebabkan karena tidak dilibatkannya para suami dalam penyuluhan. Padahal, merekalah yang menjadi pengambil keputusan dalam keluarga, termasuk dalam menentukan jumlah anak (Kishindo 1994). Demikian halnya kajian di Turki menunjukkan bahwa pelibatan laki-laki/suami dalam urusan KB (khususnya penentuan jumlah anak dan metode kontrasepsi yang akan digunakan) serta peningkatan pendidikan suami terbukti meningkatkan partisipasi laki-laki dalam ber-KB (Vural 1999).

Salah satu wilayah di Kabupaten Purbalingga yang kegiatan forum RT-nya masih berjalan adalah di Kecamatan Purbalingga. Di wilayah ini kasus perceraiannya tinggi. Menurut data tahun 2015 (Januari-Agustus), terdapat 76 kasus yang menempatkan kecamatan ini sebagai kelima terbesar di Kabupaten Purbalingga setelah Kecamatan Mrebet, Bukateja, Kaligondang dan Kejobong Pengadilan Agama Kabupaten Purbalingga dalam pa-purbalingga.go.id).

Berdasarkan pemikiran di atas, penelitian ini bertujuan untuk: (1) menggali pandangan para Ketua RT tentang perceraian di Kabupaten Purbalingga, Kecamatan Purbalingga dan di wilayah mereka, (2) menggali peran mereka dalam mencegah dan mengatasi perceraian di wilayah mereka serta (3) merumuskan model pengembangan Ketua RT sebagai "Penyuluh Keluarga" dalam upaya mencegah kasus perceraian di Purbalingga.

\section{Metode Penelitian}

Penelitian ini dilaksanakan di Kecamatan Purbalingga, Kabupaten Purbalingga dengan pertimbangan: pertama, paling banyak berdiri perusahaan rambut yang menyerap ribuan pekerja perempuan, terutama dari wilayah ini, sehingga memunculkan fenomena keluarga yang mengalami alih peran gender yang dikenal dengan plesetan "pamong praja" (papa momong mama kerja). Meski tampak harmonis, kehidupan keluarga seperti ini rentan mengalami disharmoni yang dapat berujung kepada perceraian. Kedua, memiliki jumlah kasus perceraian yang cukup banyak (terbanyak kelima sekabupaten Purbalingga). Ketiga, memiliki kelurahan/desa yang kegiatan RT-nya di banyak RT masih berjalan. Dengan pertimbangan ini, dipilih tiga kelurahan dan satu desa sebagai lokasi penelitiannya. 
Keempat lokasi tersebut adalah: Kelurahan Purbalingga Lor, Purbalingga Kidul, Bancar serta desa Toyareja.

Sasaran utamanya adalah semua Ketua RT di empat kelurahan/desa tersebut. Sasaran pendukungnya adalah para pejabat yang terkait dengan kegiatan RT dan instansi yang menangani masalah KDRT dan perceraian di tingkat kecamatan yakni: Lurah/Kepala Desa, Ketua PKK di berbagai jenjang dan Camat. Di samping itu juga tokoh agama dan Ketua RW. Metode penelitiannya adalah deskripsi kuantitatif. Data dikumpulkan melalui pemberian kuesioner yang didukung wawancara secara individu yang diperkuat dengan diskusi terfokus. Data yang terkumpul selanjutnya dianalisis dengan teknis statistik sederhana berupa tabel frekuensi yang dipertajam dengan perspektif gender.

\section{Hasil dan Pembahasan}

\section{Profil responden}

Responden penelitian ini adalah 68 orang Ketua RT di tiga kelurahan yakni Kelurahan Purbalingga Lor, Purbalingga Kidul dan Bancar serta satu desa yakni Desa Toyareja. Dari sejumlah 68 orang tersebut, mayoritasnya adalah laki-laki dan hanya ada 6 (enam) responden perempuan $(8,82$ persen). Kebanyakan dari mereka (termasuk responden perempuan) berumur antara 40-60 tahun. Namun ada juga responden laki-laki yang berumur lebih dari 70 tahun.

Tabel 1.

Umur Responden

\begin{tabular}{ccccc}
\hline Umur & \multicolumn{4}{c}{ Responden } \\
& $\mathrm{L}$ & $\mathrm{P}$ & Jumlah & $\%$ \\
\hline$<30$ th & 1 & 0 & 1 & 1,47 \\
$30-<40$ th & 3 & 0 & 3 & 4,41 \\
$40-<50$ th & 20 & 2 & 22 & 32,35 \\
$50-<60$ th & 20 & 4 & 24 & 35,29 \\
$60-<70$ th & 15 & 0 & 15 & 22,06 \\
$70>$ & 3 & 0 & 3 & 4,41 \\
\hline Jumlah & 62 & 6 & 68 & 100,00 \\
\hline
\end{tabular}

Sumber: data primer diolah

Sebagian besar responden (termasuk responden perempuan) berpendidikan SLTA (41,18 persen). Cukup banyak pula mereka yang berpendidikan baik SMP maupun D2 dan S1 dengan jumlah yang berimbang, namun ada juga yang hanya berpendidikan SD. Sebaliknya, ada pula yang berpendidikan hingga $\mathrm{S} 2$.

Tabel 2.

Tingkat Pendidikan Responden

\begin{tabular}{lcccc}
\hline \multirow{2}{*}{ Umur } & \multicolumn{4}{c}{ Responden } \\
& $\mathrm{L}$ & $\mathrm{P}$ & Jumlah & $\%$ \\
\hline SD & 11 & 0 & 11 & 16,18 \\
SLTP & 12 & 2 & 14 & 20,59 \\
SLTA & 25 & 3 & 28 & 41,18 \\
D2 \& S1 & 13 & 1 & 14 & 20,59 \\
S2 & 1 & 0 & 1 & 1,47 \\
\hline \multicolumn{1}{c}{ Jumlah } & 62 & 6 & 68 & 100,00 \\
\hline
\end{tabular}

Sumber: Diolah dari data primer 
Sementara itu, dilihat dari pekerjaan, sebagian besar dari responden memiliki pekerjaan yang bernilai ekonomi yang kebanyakan adalah sebagai Pegawai Negeri Sipil (PNS) dan TNI (22,05 persen). Pekerjaan terbanyak kedua adalah sebagai wiraswasta dan petani (khususnya di desa Toyareja) yang disusul dengan pensiunan. Dengan kata lain, pekerjaan sebagai Ketua RT yang tidak digaji ini adalah "pekerjaan sambilan" yang dilakukan di luar/setelah pekerjaan wajib/utama mereka yang kebanyakan bernilai ekonomi, namun demikian ada juga beberapa responden yang tidak memiliki pekerjaan tetap dan bahkan menganggur.Ini terjadi di wilayah pedesaan. Adapun untuk responden perempuan, hampir semuanya adalah ibu rumah tangga yang secara formal tidak dianggap sebagai pekerja.

Tabel 3.

Jenis Pekerjaan Responden

\begin{tabular}{|c|c|c|c|c|}
\hline \multirow{2}{*}{ Pekerjaan } & \multicolumn{3}{|c|}{ Responden } & \multirow{2}{*}{$\%$} \\
\hline & $\mathrm{L}$ & $\mathrm{P}$ & Jumlah & \\
\hline PNS \& Polri & 15 & 0 & 15 & 22,06 \\
\hline Pensiunan (PNS \& TNI) & 11 & 2 & 13 & 19,12 \\
\hline Ibu rumah tangga & 0 & 4 & 4 & 5,88 \\
\hline Wiraswasta \& petani & 19 & 0 & 19 & 27,94 \\
\hline Guru \& Kepala Sekolah & 6 & 0 & 6 & 8,82 \\
\hline Perangkat desa & 1 & 0 & 1 & 1,47 \\
\hline Lain-lain & 10 & 0 & 10 & 14,71 \\
\hline Jumlah & 62 & 6 & 68 & 100 \\
\hline
\end{tabular}

Sumber: data primer diolah

Dari profil di atas dapat disimpulkan bahwa para responden pada umumnya adalah mereka yang berusia sedang dan mendekati tua, berpendidikan menengah (SMA) serta memiliki pekerjaan utama yang bernilai ekonomis. Demikian halnya para responden perempuan, kebanyakan adalah mereka yang berusia sedang dan berpendidikan menengah, akan tetapi kebanyakan tidak mempunyai pekerjaan tetap yang bernilai ekonomi.

\section{Pandangan tentang perceraian di Purbalingga}

Sebagian besar responden termasuk responden perempuan (60,29 persen) menyatakan ketidak/kurangtahuan mereka tentang kondisi perceraian di Kabupaten Purbalingga. Sementara itu, sekitar sepertiga responden (35,29 persen) menyatakan bahwa fenomenanya banyak dan meningkat dikarenakan masalah ekonomi. Adapun tiga responden menyatakan bahwa kasusnya sedikit dan biasa saja.

Tabel 4.

Pemahaman Responden tentang Fenomena Perceraian di Kabupaten Purbalingga

\begin{tabular}{lcccc}
\hline \multicolumn{1}{c}{ Jawaban } & \multicolumn{4}{c}{ Jumlah Responden } \\
& L & P & Jumlah & $\%$ \\
\hline Banyak dan meningkat & 23 & 1 & 24 & 35,29 \\
Biasa saja & 2 & 0 & 2 & 2,94 \\
Sedikit & 1 & 0 & 1 & 1,47 \\
Tidak/kurang tahu & 36 & 5 & 41 & 60,29 \\
\hline \multicolumn{1}{c}{ Jumlah } & 62 & 6 & 68 & 100 \\
\hline
\end{tabular}

Sumber: data primer diolah 
Gambaran jawaban yang serupa juga terjadi menyangkut pengetahuan responden tentang fenomena perceraian di Kecamatan Purbalingga. Sebanyak 61,76 persen responden (termasuk semua responden perempuan) mengaku tidak/kurang tahu tentang hal tersebut.

Sementara itu, terhadap fenomena perceraian di wilayah tempat tinggal mereka, sebagian besar responden (57,35 persen), termasuk responden perempuan, mengatakan bahwa selama masa tugas mereka menjadi Ketua RT, belum pernah ada kasus perceraian. Adapun 42,65 persen lainnya (termasuk seorang responden perempuan) menyatakan pernah ada kasus.

Tabel 5.

Pemahaman Responden tentang Fenomena Perceraian di Wilayah Tempat Tinggal Responden

\begin{tabular}{lcccc}
\hline \multirow{2}{*}{ Jawaban } & \multicolumn{4}{c}{ Jumlah Responden } \\
& $\mathrm{L}$ & $\mathrm{P}$ & Jumlah & $\%$ \\
\hline Ada & 28 & 1 & 29 & 42,65 \\
Tidak ada & 34 & 5 & 39 & 57,35 \\
\hline Jumlah & 62 & 6 & 68 & 100 \\
\hline
\end{tabular}

Sumber: data primer diolah

Di kalangan responden yang mengatakan pernah ada kasus selama mereka menjadi Ketua RT, jumlah kasusnya berkisar antara satu hingga tiga kasus dengan total kasus sebanyak 30 kasus. Dari jumlah ini, hampir semua kasusnya (90 persen) adalah gugat cerai oleh istri. Di kalangan tiga suami yang mengajukan talak, penyebabnya adalah karena ketidakharmonisan dengan pasangan serta karena istri selingkuh. Adapun di kalangan istri yang menggugat cerai, kebanyakan kasusnya adalah karena problem ekonomi di mana suami dianggap tidak dapat memenuhi kewajiban mencari nafkah. Hal ini sebagiannya terjadi karena suami adalah pekerja serabutan atau bahkan pengangguran. Penyebab lainnya adalah karena suami selingkuh dan adanya KDRT oleh suami. Hampir semua kasus ini berakhir dengan perceraian dan hanya ada satu kasus yang dapat dibatalkan.

Dari gambaran di atas tampak bahwa salah satu penyebab perceraian adalah karena masalah ekonomi di mana sebagian di antaranya disebabkan suami yang tidak bekerja secara penuh (pekerja serabutan) atau bahkan pengangguran. Hal ini sesuai dengan jawaban sebagian 13 responden $(19,12$ persen) yang mengatakan bahwa di lingkungan warganya terdapat keluarga yang secara ekonomi didominasi oleh istri. Sebagian dari istri tersebut adalah pekerja di perusahaan rambut yang banyak tersebar di Kecamatan Purbalingga. Menurut mereka, sebagian dari keluarga tersebut memiliki beberapa permasalahan. Misalnya, percekcokan, perselingkuhan (baik yang dilakukan oleh suami maupun istri) serta pengasuhan anak yang lebih ditangani oleh nenek. Permasalahan lainnya adalah kesulitan mendidik anak-anak yang mulai beranjak remaja.

\section{Upaya pencegahan kasus perceraian di wilayah tempat tinggal responden}

Selama responden menjadi Ketua RT, terdapat 30 kasus perceraian yang diajukan, baik oleh pihak istri maupun suami di mana hampir semuanya diajukan oleh istri.Penyebab terbanyak kasusnya adalah karena faktor kekurangan ekonomi karena banyak suami yang berpenghasilan tidak tetap dan beberapa orang bahkan menganggur.

Sebagian besar responden mengatakan bahwa mereka nyaris tidak bisa mencegah kasus perceraian di wilayah mereka. Penyebabnya adalah pada saat pemohon perceraian datang kepada mereka untuk minta surat pengantar, kasus mereka sudah berjalan lama dan mereka kebanyakan bersikukuh untuk tetap mengajukan perceraian. Dalam istilah responden, kasus mereka sudah dalam kondisi "stadium 3", sehingga susah untuk disembuhkan. Pada akhirnya, kebanyakan kasusnya berakhir dengan keputusan cerai. 


\section{Model optimalisasi peran Ketua RT sebagai penyuluh keluarga dalam upaya pencegahan perceraian}

Dari pemetaan kondisi di lapangan tampak bahwa selama ini kelompok warga laki-laki sangat jarang mendapat sosialisasi seputar permasalahan keluarga, misalnya tentang hak dan kewajiban suami istri dan UU PKDRT. Hanya beberapa responden yang berani memberikannya pada saat pelaksanaan forum RT, disebabkan mereka memiliki cukup ilmu tentang hal tersebut terutama dari perspektif agama. Beberapa responden lainnya juga pernah mendapatkan ilmu tersebut dari warga yang mempunyai cukup ilmu tentang agama.

Kondisi sebaliknya terjadi dengan kebanyakan warga perempuan di tingkat RT yang memiliki forum aktivitas sosial bulanan yang banyak. Untuk kegiatan PKK, aktivitasnya ada di tingkat yang paling rendah yakni Dasa Wisma (biasanya 20 rumah yang paling berdekatan), tingkat RT, RW hingga kelurahan/Desa. Semakin dia aktif dan menjadi Pengurus, maka semakin banyak jenjang pertemuan yang diikutinya. Belum lagi aktivitas pengajian yang saat ini juga semakin marak di berbagai tingkatan. Di setiap pertemuan PKK hampir selalu diisi oleh tausiah (siraman rohani agama Islam) dan informasi berbagai hal terutama di bidang kesehatan, pendidikan dan masalah keluarga lainnya maupun peningkatan keterampilan. Dengan demikian sebetulnya warga perempuan (khususnya yang menjadi kader) semakin hari semakin berilmu. Untuk itulah, sebetulnya mereka dapat ikut memberdayakan pengurus RT di lingkungannya guna menjadi sarana penyambung sosialisasi berbagai topik keluarga bagi kalangan warga laki-laki. Mereka dapat mendampingi Ketua RT di wilayahnya pada saat sosialisasi kepada kalangan warga laki-laki di forum RT. Hal tersebut tergambar dari model pada Gambar 1.

Sementara itu, sebagian responden menyatakan bahwa mereka bersedia menjadi kader keluarga dengan syarat sebelumnya diberikan pelatihan terlebih dahulu yang diberikan oleh para pakar di bidangnya maupun oleh pegawai-pegawai dari instansi yang bertugas untuk itu. Misalnya, Penyuluh KB dari BKBPP, penyuluh Agama dari Kementerian Agama dan petugas Puskesmas. Lembaga lain yang berkompeten adalah Tim "Harapan" (Hapus Kekerasan pada Anak dan Perempuan) yang merupakan gabungan instansi di Kabupaten Purbalingga yang memiliki tugas dan fungsi mencegah dan menangani kasus-kasus kekeraan pada perempuan dan anak. Disebabkan keterbatasan dana dan tenaga, tim ini menjadi sangat tidak dikenal warga. Padahal sebetulnya sebagai tim gabungan, sumberdayanya sangat mendukung untuk melakukan aksi pencegahan dan penanganan kasus KDRT. Dengan demikian, apabila tim ini lebih aktif menyosialisasikan, maka sangat dimungkinkan upaya pencegahannya menjadi lebih efektif. 
Tidak ada pertemuan RW maupun RT di tingkat Kabupaten<smiles>CCCCCCCC</smiles>

Tidak ada pertemuan RW maupun RT di tingkat Kecamatan

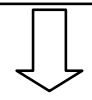

Tidak ada pertemuan RW di tingkat Kelurahan<smiles>C1CCCCC1</smiles>

Pertemuan RT di tingkat Kelurahan/Desa: Insidental, hampir semua yang hadir laki-

laki, malam hari; materi info pembangunan (Adipura, jalan, PBB), penyuluhan yg mewabah

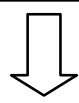

Tidak ada pertemuan RW di tingkat RW

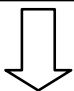

Pertemuan RT di tingkat RT:

Banyak yg rutin bulanan, hampir semua yang hadir laki-laki, malam hari, materi; info dr Kelurahan/Desa, program pembangunan di tingkat RT, arisan, ngobrol

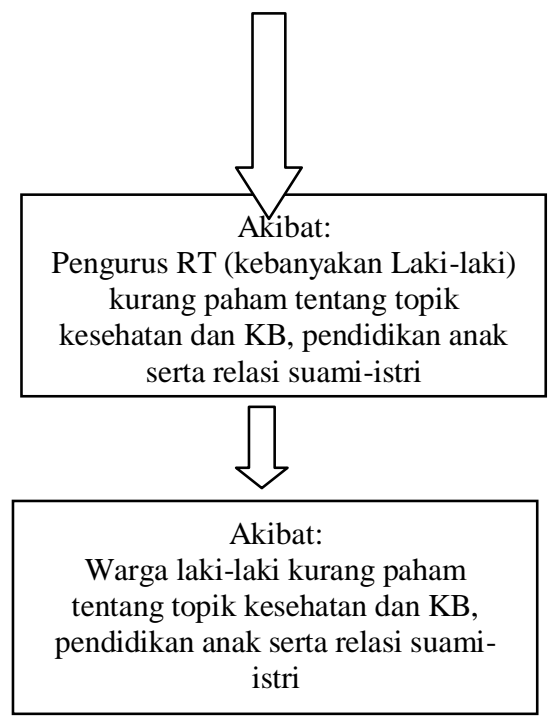

Pertemuan PKK Kabupaten: rutin bulanan, semuanya perempuan, pagi hari

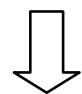

Pertemuan PKK tingkat

Kecamatan:

rutin bulanan,

semuanya

perempuan, pagi

hari

Pertemuan tingkat
Kecamatan
(Kader Kesehatan
dengan
Puskesmas):
Semuanya
perempuan, pagi
hari

hari

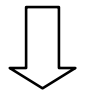

Pertemuan PKK Kelurahan/Desa: rutin bulanan, semuanya perempuan, pagi hari; materi $\rightarrow$ program pembangunan, kesehatan \& KB, agama dan arisan

Pertemuan PKK RW: rutin

bulanan, semuanya perempuan; sore hari

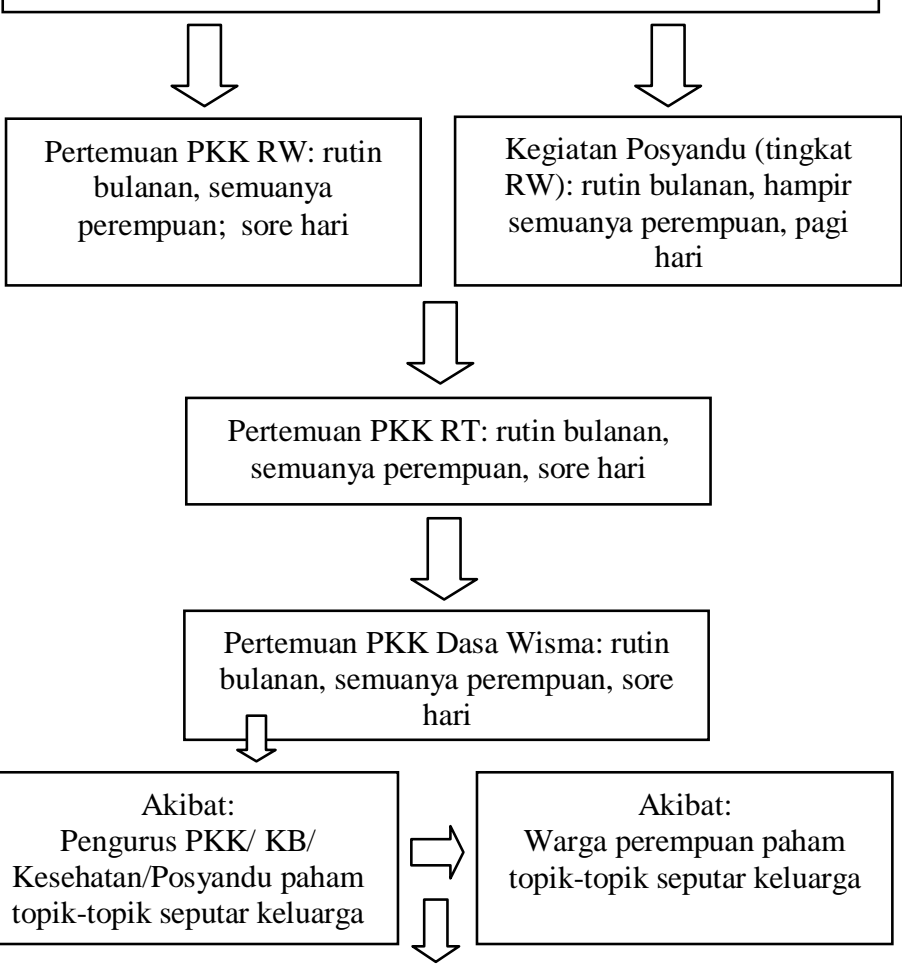

Pertemuan tk. Kec (Ka PUT BKBPP/

PKB dengan

Kader KB):

Semuanya

perempuan, pagi

hari

Hampir tidak pernah menyosialisasikan ke kelompok laki-laki

Dampak: akseptor laki-laki sedikit, KDRT + perceraian tinggi

Dampak: Kesenjangan pengetahuan, sikap dan keterampilan tentang urusan domestik

\section{Gambar 1.}

Existing Model Forum di Rukun Tetangga saat ini 
Dengan pemikiran seperti itu, maka model yang diusulkan untuk optimalisasi peran Ketua RT sebagai penyuluh keluarga dalam upaya pencegahan kasus KDRT dan perceraian adalah sebagai berikut.

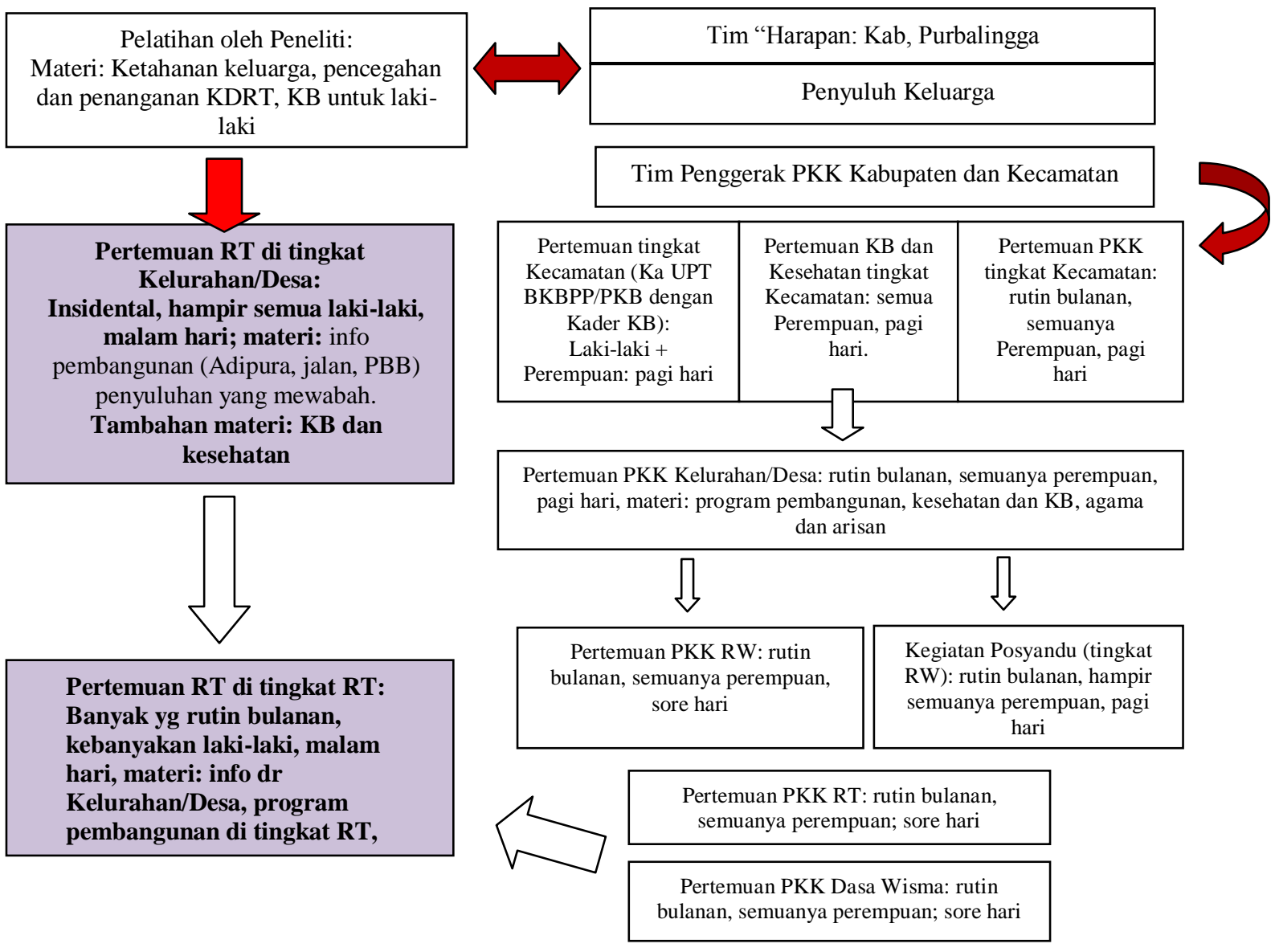

Gambar 2.

Suggestion Model pembentukan kader Keluarga Berencana dari kalangan pengurus Rukun Tetangga

\section{Simpulan}

Dari hasil penelitian ini dapat disimpulkan bahwa kebanyakan responden belum mengetahui secara pasti tentang fenomena perceraian di Kabupaten dan Kecamatan Purbalingga serta di wilayah mereka. Kebanyakan responden (yang di wilayahnya terdapat kasus perceraian) tidak bisa menahan terjadinya perceraian, karena warga yang menjadi pemohon perceraian pada umumnya sudah bulat keputusan untuk bercerai.

Untuk itulah perlu dibuat suatu model upaya pencegahan dengan cara mengoptimalkan forum RT (yang kebanyakan diikuti warga laki-laki) dengan topik ketahanan keluarga. Dalam hal ini Ketua RT berperan sebagai penyuluh. Untuk mencapai hal ini, diperlukan pelatihan pembekalan bagi mereka.

\section{Daftar Pustaka}

Direktorat Jenderal Badan Peradilan Agama (Badilag) Mahkamah Agung RI.(n.d.) http://www.badilag.net/rekap-perkara-diterima-dan-diputus).[diakses 30 Mei 2010]

Flood M (2010) Where Men Stand: Men's Roles in Ending Violence against Women. Sydney: White Ribbon Prevention Research Series, No. 2.

Imroni M, Fajar NA, Febry F (2009) Faktor-faktor yang Berhubungan dengan Penggunaan Implan di Desa Parit Kecamatan Indralaya Utara Kabupaten Ogan Ilir Tahun 2009. Upm.fkm.unsri.ac/id/uploads/files/u_Absrk3.doc.[3 Oktober 2010]. 
Kishindo P (1994) Family Planning and the Malawian Male. Journal of Social Development in Africa. 1994, 9, 2, p. 61-69.

http://archive.lib.msu/DMC/.African\%20Journals/pdfs/social\%20development/vol9no2/jsda0 092008.Pdf. [diakses30 Mei 2010].

Pengadilan Tinggi Agama Semarang(n.d.) dalam http://www.ptasemarang.go.id/kepaniteraan/arsip/Faktorceraipbr2011.pdf.

Pengadilan Agama Kabupaten Purbalingga (n.d.) dalam (http://pa-

Purbalingga.go.id/index.php?option=com_content \&view=article\&id=404\&Itemid=192\&lang=i d). [diakses 30 Mei 2010]

Puspita DR, Rostikawati R, Lilis SS (2014) Model Penyuluhan KB Berbasis Gender dalam Mencegah Kekerasan dalam Rumah Tangga di Kabupaten Purbalingga. Jurnal Dinamika Hukum Vol. 3 Nomor 14 Edisi September 2014.

Undang-undang Nomor 52 Tahun (2009) tentang Perkembangan Kependudukan dan Pembangunan Keluarga.http://www.depkop.go.id/attachments/article/1465/03.\%20UU-23th2004penghapusan\%20kekerasan\%20dalam\%20rumah\%20tangga.pdf.

Undang-undang Nomor 1 (1974) tentang Perkawinan.http://www.kemenag.go.id/file/dokumen/UUPerkawinan.pdf.

Vural BF, Vural JD dan Yucesoy I (1999) Factors Affecting Contraseptive Use and Behavior in Kocaeli, Turki. Journal "Advance in Contraceptive".Volume 15, Number 4/ December, 1999. ISSN: 0267-4874. http://www.springerlink.com/content/g711165118413702/.[28 Mei 2010]. 